\title{
Digeorge Syndrome in a Neonate
}

\author{
Mayank Jain ${ }^{1 *}$, Priya Jain², Poonam Sidana ${ }^{3}$ and A P Mehta ${ }^{4}$ \\ ${ }^{1}$ Fellow, Neonatology, Max Hospital, Shalimar Bagh, Delhi \\ ${ }^{2}$ Senior Resident, Pathology, St Stephens Hospital, Delhi \\ ${ }^{3}$ Consultant \& Head, Neonatology, Max Hospital, Shalimar Bagh, Delhi \\ ${ }^{4}$ Consultant, Neonatology, Max Hospital, Shalimar Bagh, Delhi
}

Submission: November 13, 2019; Published: December 11, 2019

*Corresponding author: Mayank Jain, Fellow, Neonatology, Max Hospital, Shalimar Bagh, Delhi

\begin{abstract}
Di George Syndrome is an autosomal dominant disorder with a prevalence rate of 1 in 4000 live birth. The most common chromosomal abnormality associated is the microdeletion of chromosome 22q11.2, followed by 10p13. Most of the patient present with abnormal facial features along with velocardial abnormalities. Here we report a case of Digeorge Syndrome in a neonate with no associated facial features or behavioral pattern. However, laboratory findings, as well as genetic study helped us to reach the diagnosis.
\end{abstract}

Keywords: Digeorge syndrome; Hypocalcemia; Chromosomal anomaly; Microdeletion

\section{Introduction}

Di George Syndrome is an autosomal dominant disorder with a prevalence rate of 1 in 4000 live birth [1,2]. The most common chromosomal abnormality associated is the microdeletion of chromosome 22q11.2, followed by $10 \mathrm{p} 13$ [3]. The primary immunodeficiency is associated with abnormal facial appearance, congenital heart defects, hypoparathyroidism with hypocalcemia. Facial featuresinclude hypertelorism, micrognathia, antimongoloid slant and short philtrum [4]. However; not all patients have typical facial appearance and diagnosis may get delayed for many years till the patient present with clinical symptoms [5].

\section{Case Report}

A $2.5 \mathrm{~kg}$ single preterm female (34 weeks 3 days) child was admitted in NICU delivered via LSCS. Mother had a bad obstetric history with gestational diabetes mellitus and polyhydramnios. There was previous history of medical termination of pregnancy due to cardiac anomaly. Immediately after the delivery the baby had mild respiratory distress for which she received delivery room CPAP. Baby was shifted to NICU in the incubator with ventilatory support. Initial sepsis screen was negative but repeated desaturation was observed. Repeat sepsis screen showed CRP0.66. Procalcitonin was negative. The baby had two episodes of apnea with desaturation, bradycardia and bluish discoloration. Baby was put on tube feeds. Since large volume feeds were not tolerated, baby was given two hourly feeds instead of three hourly feeds. The baby had repeated vomiting, so prokinetics were also given. Antibiotics were also added as repeat CRP was high. On examination heart rate was 130 beats/minute, respiratory rate$46 /$ minute. Initial $\mathrm{spO}_{2}>95 \%$ on room air. Heart sounds were normally heard. Arterial blood gas was in acceptable range except ionic calcium which was low. Serum calcium was also low so correction for calcium was done. Vitamin D levels were also low. Lumbar Puncture was done to rule out meningitis which was normal. To rule out metabolic cause, serum ammonia levels were also done which was within normal range. Lactates were also within normal range in blood gas analysis. Chest X-ray was normal. USG Cranium was within normal limits. Echocardiography showed no congenital heart defects. In view of repeated desaturation, bluish discoloration with hypocalcemia despite correction with calcium and vitamin D, sample was sent for microarray which showed microdeletion of chromosome 22q11.2 (Figure 1 and 2). Although no gross facial dysmorphism was observed at the time of birth. Regular follow up will be required for behavioral pattern and mental health. 


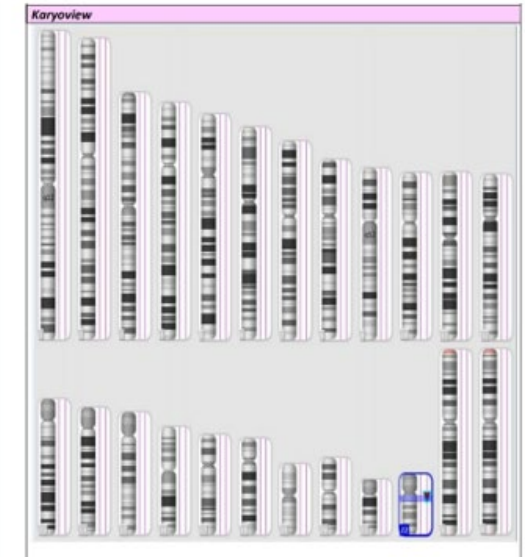

Figure 1: Karyoview.

\begin{tabular}{|c|c|}
\hline \multicolumn{2}{|c|}{ 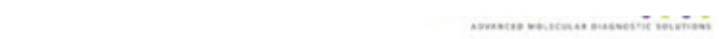 } \\
\hline CONTENTS & RESULT \\
\hline \multicolumn{2}{|l|}{ Autosomal Aneuploidies } \\
\hline Trisomy 21 (Down syndrome) & Negative \\
\hline Trisomy 18 (Edwards syndrome) & Negative \\
\hline Trisomy 13 (Patau syndrome) & Negative \\
\hline Other autosomal aneuploidies & Negative \\
\hline \multicolumn{2}{|l|}{ Sex Chromosome Aneuploidies } \\
\hline Monosomy X(Turner syndrome) & Negative \\
\hline XYY (Jacobs syndrome) & Negative \\
\hline XOY (Klinefeitter syndrome) & Negative \\
\hline XOX (Triple X syndrome) & Negative \\
\hline \multicolumn{2}{|l|}{ Euploidy } \\
\hline Triploidy & Negative \\
\hline \multicolumn{2}{|l|}{ Clinically significant Genome-wide copy number variations } \\
\hline Gains & Negative \\
\hline Losses & Positive \\
\hline \multicolumn{2}{|l|}{ Select Microdeletions } \\
\hline 22q11 deletion (associated with DiGeorge Syndrome) & Positive \\
\hline 15q11 deletion (associated with Prader-Willi/ Angelman syndrome) & Negative \\
\hline 11 q23 deletion (associated with Jacobsen syndrome) & Negative \\
\hline 8924 deletion (associated with Langer-Giedion syndrome) & Negative \\
\hline Sp15 deletion (associated with Cri-du-chat syndrome) & Negative \\
\hline 4p16 deletion (associated with Wolf-Hirschhorn syndrome) & Negative \\
\hline 1 36 deletion syndrome & Negative \\
\hline Other microdeletion syndromes & Negative \\
\hline
\end{tabular}

Figure 2: Chromosomal analysis.

\section{Discussion}

Digeorge syndrome occurs sporadically and seen in 1 in 4000 live births. 2 It is mainly associated with failure of development of third and fourth branchial pouch [6]. Molsted et al. suggested the failure of migration of neural crest during the 4th week of embryogenesis [7]. Most specific method for diagnosis of Digeorge Syndrome is FISH, which shows microdeletion of chromosome 22q11. However, not all patients with 22q11.2 deletion always show all features of Digeorge Syndrome [8]. In some cases, hypothyroidism can be the only anomaly with no associated cardiac or immunological defects [9]. Prompt diagnosis and relevant investigations are important in patients with a very early presentation for a definitive diagnosis. In our case recurrent apnea and hypocalcemia pointed towards a possibility 
of Digeorge syndrome which was later confirmed by karyotyping features. There was no cardiac anomaly or facial dysmorphism in our case. The mortality rate is higher in the first year of life if cardiac anomaly is present. Cardiac anomaly is seen in $75 \%$ of patients with 22q11.2 deletion [10]. Neonates presenting with hypocalcemia are given a low phosphorus diet. Also, live vaccines are not advised in these patients [11]. Genetic workup can be done in parents of such children to see if there is chromosomal deletion in either parent. This helps in assessing the risk of inheritance in subsequent children. Karyotyping and FISH play an important role in early and definitive diagnosis [12].

\section{Conclusion}

With prompt diagnosis and early treatment, baby had shown improvement and was discharged subsequently. However, regular follow up was advised to assess possible behavioral and mental disorders.

\section{References}

1. Devriendt K, Fryns JP, Mortier G, van Thienen MN, Keymolen K (1998) The annual incidence of DiGeorge/velocardiofacial syndrome. J Med Genet 35: 789-790.

2. Driscoll AD, Sullivan EK (2007) DiGeorge syndrome: A chromosome 22q11.2 deletion syndrome. In Primary immunodeficiency diseases. $2^{\text {nd }}$ Edn. Oxford Uni Press 485-495.

3. Zammit A, Psaila J, Attard A (2013) Di George Syndrome Presenting as Hypocalcaemia Induced Seizures in adulthood. Hindawi.
4. Butts SC (2009) The facial phenotype of the velo-cardio-facial syndrome. Int J Pediatr Otorhinolaryngol 73(3): 343-350.

5. Johnston PC, Donnelly DK, Morrison PJ, Hunter SJ (2008) DiGeorge syndrome presenting as late onset hypocalcaemia in adulthood. Ulster Med J 77(3): 201-202.

6. HB Robinson (1975) DiGeorge's or the III-IV pharyngeal pouch syndrome: pathology and a theory of pathogenesis. Perspect Pediatr Pathol 2: 173-206.

7. K Mølsted, M. Boers, I Kjär (2010) The morphology of the sella turcica in velocardiofacial syndrome suggests involvement of a neural crest developmental field. Am J Med Genet A 152A(6): 1450-1457.

8. Hacıhamdioğlu B, Berberoğlu M, Şıklar Z, Doğu F, Bilir P et al. (2011) Case Report: Two Patients with Partial DiGeorge Syndrome Presenting with Attention Disorder and Learning Difficulties. J Clin Res Ped Endo 3(2): 95-97.

9. Van den Berge K, Diderich K, Poddighe P, Berghout A (2009) Symptomatic hypoparathyroidism based on a 22q11 deletion first diagnosed in a 43-year-old woman. Neth J Med 67(3): 102-104.

10. Cuneo BF (2001) 22q11.2 deletion syndrome: DiGeorge, velocardiofacial, and conotruncal anomaly face syndromes. Curr Opin Pediatr 13(5): 465-472.

11. Joshi P and Dabas H (2017) Managing a newborn with Di George Syndrome. International Journal of Current Innovation Research 3(5): 671-673.

12. Wilson DI, Burn J, Scambler P, Goodship J (1993) DiGeorge syndrome: part of CATCH 22. Med Genet 30(10): 852-856.

\section{Your next submission with Juniper Publishers will reach you the below assets}

- Quality Editorial service

- Swift Peer Review

- Reprints availability

- E-prints Service

- Manuscript Podcast for convenient understanding

- Global attainment for your research

- Manuscript accessibility in different formats

( Pdf, E-pub, Full Text, Audio)

- Unceasing customer service

Track the below URL for one-step submission

https://juniperpublishers.com/online-submission.php 